\title{
Biophysical alteration of lung surfactant by extracts of cotton dust
}

\author{
Anthony J DeLucca II, Kim A Brogden, Edwin A Catalano, Nancy M Morris
}

\begin{abstract}
Byssinosis, a lung disease that can affect cotton mill workers, may be caused in part by lipopolysaccharides (LPS) from Gram negative bacteria. In vitro, LPS complexes with sheep lung surfactant (SLS). To determine whether LPS in extracts of cotton dust alters the biophysical characteristics of lung surfactant, aqueous extracts (1.0\% w:v) of sterile surgical cotton (SSC) and a bulk raw cotton dust (1182DB) were prepared. Aliquots of the soluble extracts were incubated with SLS and studied by sucrose gradient centrifugation, surface tension analysis, and high pressure liquid chromatography (HPLC). The chromatography was employed to analyse for 3-hydroxymyristate (3-HM), a fatty acid indicating LPS. Also, purified Enterobacter agglomerans LPS and 3-HM as controls and as mixtures with SLS, were studied by HPLC. Sucrose gradient centrifugation showed that SLS-SSC, SLS-1182DB, and the SLS control had similar densities that differed from the remaining controls. The SLS-1182DB exhibited a floccule absent in the other samples. Surface tension values of SLS-SSC and SLS-1182DB differed significantly from all controls but only slightly from one another. 3Hydroxymyristate was detected by HPLC in the 3-HM control, EA-LPS, SLS-EA-LPS, and SLS-1182DB, but not in SLS-SSC or the remaining controls. Apparently, 3-HM was below the HPLC detection range in SSC. The data indicate that LPS in the 1182DB, SSC and EA-LPS samples complexed with SLS. Floccule development in SLS-1182DB but not in
\end{abstract}

Composition and Properties Research Unit, Southern Regional Research Center, 1100 Robert E. Lee Blvd, New Orleans, Louisiana, USA

A J DeLucca II, E A Catalano, N M Morris

Respiratory Disease Research Unit, National Animal Disease Center, Ames, Iowa 50010, USA K A Brogden
SLS-EA-LPS suggests a further component(s) present in the bulk raw cotton dust, as well as LPS, which complexes with SLS. The data suggest that biophysical alterations to lung surfactant may play a part in the pathogenesis of byssinosis.

Mill workers inhaling organic dusts (cotton, flax, or hemp dusts) may develop a respiratory disease known as byssinosis. ${ }^{1-3}$ This lung dysfunction is characterised by chest tightness on the first day of the work week accompanied by an impairment of respiratory function. ${ }^{4}$ Fever with influenza-like symptoms may occur on the first occasion of exposure. Febrile reaction can reappear after a prolonged absence from work after a heavy exposure. ${ }^{4}$ The impairment of pulmonary function is due to bronchoconstriction. The extent of bronchoconstriction can be determined by measuring the forced expiratory flow in one second. Subjectively, this respiratory impairment is indicated by a feeling of chest tightness that develops slowly on the afternoon of the first day of the work week after long exposure to the airborne dusts. ${ }^{4}$

The aetiological agent(s) of this lung dysfunction have been shown to be in the respirable cotton dusts found in the air of mills, ${ }^{35}$ but not in the cellulose portion of cotton dusts. ${ }^{6}$ Although the causative agents of this disease have not been definitively determined, research has indicated that Gram negative bacterial lipopolysaccharides (LPS) are an important factor in its pathogenesis. ${ }^{278}$

The mechanism of the disease process is complex and not yet fully understood. It is known that the small particle size of the respirable dust allows penetration into the lung and alveoli where the disease producing agent(s) is solubilised. ${ }^{9}$ Numerous pathophysiological changes in animals are induced by LPS including damage to vascular endothelial cells and haematological changes. ${ }^{10}$ Recruitment of neutrophils and stimulation of platelet activating factor by alveolar macrophages occur in the lung after inhalation. ${ }^{11}$ The bronchoconstriction common in byssinosis appears to be due to an acute inflammatory reaction and not to histamine or mast cell mediator release alone. ${ }^{912}$ The acute inflammatory response 
may be due to breakdown products originating from cell membrane phospholipids. ${ }^{9}$

Surfactant of mammalian lung is composed of a lipid proteinacious material (including phospholipids) which coats the interior of the lung. ${ }^{13}$ It imparts homeostasis and alveolar stability by acting reversibly to reduce the surface tension at the air interface with the alveolus. ${ }^{14}{ }^{15}$ Also, lung surfactant may take part in protection of the lung against disease. Surfactant may be protective against receptor mediated allergic reaction in the bronchi. ${ }^{16}$ This material also aids in the removal of foreign particles from the airways, ${ }^{1718}$ and stimulates motility ${ }^{19}$ and phagocytotic and bactericidal capacity of alveolar macrophages. ${ }^{1820}$

Lung surfactant has also been implicated in the pathology of certain pulmonary diseases. Newborn babies, functionally deficient in lung surfactant, can suffer from respiratory distress syndrome. This disease is primarily characterised by diffuse atelectasis (lung collapse) in the affected infants. ${ }^{21}$ Other types of lung injury such as the adult respiratory distress syndrome and hyperoxia are associated with alterations in lung surfactant..$^{22-24}$ Therefore, damage to surfactant or impairment of its production may have a deleterious effect on lung function and hence life itself. ${ }^{25}$

Earlier work has shown that the sheep lung and its secretions are a successful model for the study of respiratory disease. Bacterial LPS binds with sheep lung surfactant to form a complex with properties different from those of either compound. ${ }^{26} 27$ Enterobacter agglomerans is one of the major bacterial species found on parts of cotton plants ${ }^{128-30}$ and in the air of cotton mills. ${ }^{131}$ Purified LPS from this bacterium complexes with sheep lung surfactant, thereby altering the biophysical properties of both materials. ${ }^{32}$

It has been established that unaffected lung surfactant is important to normal pulmonary function whereas altered surfactant is associated with certain pulmonary diseases. Purified LPS from a common cotton bacterium can alter the physical properties of surfactant. Our research was performed to determine whether LPS in raw cotton dust could also change the physical properties of surfactant in vitro. Such an effect could suggest a possible role of compromised lung surfactant in the development of the byssinosis syndrome.

\section{Materials and methods}

Bulk raw cotton dust (1182DB) and sterile surgical cotton (SSC, American White Cross Laboratories Inc, New Rochelle, NY) were used to study the effect on lung surfactant. The $1182 \mathrm{DB}$ was from the same batch that was used to develop an animal model for byssinosis. ${ }^{6}$ The cotton dust was generated in a textile mill from bright low middling grade of unspecified varieties purchased in the Memphis area from the 1982 crop. ${ }^{6}$

Aqueous extracts ( $1 \% \mathrm{w}: \mathrm{v})$ were prepared from $1182 \mathrm{DB}$ and from SSC by gentle stirring in pyrogen free water overnight at $4^{\circ} \mathrm{C}$. The mixture was centrifuged $(1450 \mathrm{~g})$ for 30 minutes at $4^{\circ} \mathrm{C}$. The supernatant was decanted and was further clarified by filtration through a sterile $0.45 \mu$ filter unit (Nalgene Co, Rochester, N Y). The clarified supernatant (1:100 dilution of the cotton samples) was then frozen and stored at $0^{\circ} \mathrm{C}$ until needed.

Surfactant was recovered by lavage of excised lungs of 12 healthy adult sheep and prepared as described previously. ${ }^{33}$ An aliquot of the supernatant was extracted for phospholipid analysis of the surfactant by the method of Bligh and Dyer. ${ }^{34}$ The chloroform phase was evaporated under nitrogen. The phospholipids were resuspended in chloroform methanol hexane $(5: 4: 1)$ solution and separated by an Ultrasphere $\mathrm{Si}$ column (Beckman Instruments Inc, San Ramon, CA) by high pressure liquid chromatography (HPLC) (pump 2350 and V4 absorbance detector; ISCO Inc, Lincoln, NB). The composition of phospholipids was typical of that reported for surfactant from sheep. ${ }^{33}$ Surfactant was stored frozen until needed.

$E$ agglomerans ATCC 27996 was grown on nutrient agar (Difco Laboratories, Detroit, $\mathrm{MI}$ ) in Roux flasks and incubated at $30^{\circ} \mathrm{C}$. After 24 hours the cultures were harvested in cold, sterile, distilled water and centrifuged $(4080 \mathrm{~g})$ for 30 minutes at $4^{\circ} \mathrm{C}$. The cells were washed once with distilled water, once with acetone, twice with diethyl ether, and then dried. The LPS was extracted from $2.3 \mathrm{~g}$ (dry weight) of cells by the hot phenol water procedure. ${ }^{35}$ The combined water extracts were dialysed against water at $4^{\circ} \mathrm{C}$ for three to four days and centrifuged $(5000 \mathrm{~g})$ to remove any insoluble particles. The LPS solution was diafiltrated (YM 10; Amicon Corps, Danvers, MA) with $0.025 \mathrm{M}$ trometamol (TRIS) buffer, $\mathrm{pH} 7 \cdot 2$ and concentrated to $45 \mathrm{ml}$. RNase A (type 111A; Sigma Chemical Co, St Louis, MO) and DNase I (Sigma Chemical Co) were added to the solution at a final concentration of $100 \mu \mathrm{g} / \mathrm{ml}$ and $10 \mu \mathrm{g} / \mathrm{ml}$, respectively, and incubated at $37^{\circ} \mathrm{C}$ in a water bath for 30 minutes. Trypsin (Worthington Biochemical Group. Bedford, MA) was then added to a final concentration of $10 \mu \mathrm{g} / \mathrm{ml}$ and incubated at $37^{\circ} \mathrm{C}$ in a water bath for one hour. The LPS was pelleted from the solution by centrifugation $(105000 \mathrm{~g})$ for one hour and suspended in distilled water. The LPS was washed twice, resuspended in distilled water, and lyophilised.

Table 1 outlines the preparation of surfactant, $1182 \mathrm{DB}$, and SSC both alone and mixed for sucrose density centrifugation and surface tension analysis.

The final concentration of 1182DB dust and surgical cotton (SSC) in the mixtures with surfactant 
Table 1 Preparation of controls and mixtures for sucrose density centrifugation and surface tension analysis

\begin{tabular}{|c|c|c|c|c|c|}
\hline \multirow[b]{2}{*}{ Controls and mixtures } & \multicolumn{5}{|c|}{ Amount of solution used ( $\mathrm{ml}$ ) } \\
\hline & $\begin{array}{l}\text { Pooled } \\
\text { surfactant }\end{array}$ & $\begin{array}{l}\text { Distilled } \\
\text { water }\end{array}$ & $\begin{array}{l}\text { Tris` } \\
\text { buffer }\end{array}$ & $\begin{array}{l}1182 \\
D B \dagger\end{array}$ & $S S C+$ \\
\hline Surfactant $+\dagger$ & $1 \cdot 0$ & $1 \cdot 0$ & $2 \cdot 0$ & - & 一 \\
\hline $1182 \mathrm{DB}+\dagger$ & - & - & $2 \cdot 0$ & $2 \cdot 0$ & - \\
\hline SSC+† & - & - & $2 \cdot 0$ & - & $2 \cdot 0$ \\
\hline Surfactant $+1182 \mathrm{DB} \S \|$ & $1 \cdot 0$ & - & $1 \cdot 0$ & $2 \cdot 0$ & $\overline{0}$ \\
\hline Surfactant + SSC\&\| & $1 \cdot 0$ & - & $1 \cdot 0$ & - & $2 \cdot 0$ \\
\hline
\end{tabular}

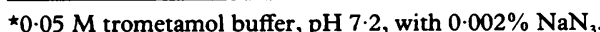

†Aqueous extract $(1.0 \%$, w:v) of bulk cotton dust (1182DB) and SSC.

t+Controls.

$\$$ Mixtures.

Concentration of cotton extract was $0.5 \%$ of the original sample after sample preparation.

was $0.5 \%$ of the original samples. These mixtures were incubated in a $37^{\circ} \mathrm{C}$ water bath for six hours with shaking at 15 minute intervals. ${ }^{32}$ Each solution was then layered separately over $28 \mathrm{ml}$ of discontinuous sucrose gradient and centrifuged as described previously. ${ }^{26}$ Fractions $(1 \mathrm{ml})$ were collected and the sucrose density of each fraction was determined after refractometer readings. Total lipids were extracted from each fraction as described, ${ }^{34}$ and the phosphorus content was determined with $\mathrm{KH}_{2} \mathrm{PO}_{4}$ and phosphatidylcholine as standards. ${ }^{36}$ Thin layer chromatography (TLC) was used to identify phospholipids (surfactant) as described by Touchstone, ${ }^{37}$ with a serum lipid mixture (Supelco Inc, Bellefonte, PA) as the standard. At least three separate sucrose density gradient runs were performed on the surfactant control and the surfactant cotton extract mixtures. Single density gradient runs were performed on the cotton extract controls.

These solutions were also placed in sterile petri dishes ( 35 by $10 \mathrm{~mm}$; Falcon, Oxnard, CA), and the surface tension was measured ${ }^{38}$ with a platinum ring attached to a surface tensiometer (model 20; Fisher Scientific Co, Pittsburg, PA). When checked with $0.025 \mathrm{M}$ trometamol buffer, $\mathrm{pH} 7 \cdot 2$, the tensiometer gave a reading of 74.3 (standard error of the mean (SEM) 0.1) dynes $/ \mathrm{cm}$. Two separate runs with 10 replications in each run were performed, for the $1182 \mathrm{DB}$, SSC, and surfactant controls as well as for the surfactant cotton dust extract mixtures.

The presence of LPS in the samples was determined by HPLC analysis of 3-hydroxymyristic acid (3-HM). This fatty acid is unique to Gram-negative bacteria (GNB) and has been used to detect lipopolysaccharide..$^{3041}$ Table 2 describes the preparation of samples for HPLC analysis and includes controls of buffer, 3-HM, and purified $E$ agglomerans LPS and mixtures of surfactant with purified $E$ agglomerans LPS, 3-HM, and the 1182DB and SSC aqueous extracts. All components (table 2) were mixed and incubated for six hours at $37^{\circ} \mathrm{C}$ in a water bath. Again, the final concentration of $1182 \mathrm{DB}$ dust and SSC in the mixtures with surfactant was $0.5 \%$ of the original sample.

To eliminate interference from non-reacted components the surfactant mixtures were layered over sucrose gradients before HPLC. The controls were directly analysed by HPLC without previous purification by sucrose gradient. The discontinuous sucrose gradient centrifugation was performed as described earlier. The surfactant controls and the surfactant mixtures were fractionated into $1.0 \mathrm{ml}$ aliquots. The aliquots were assayed for the presence of surfactant by TLC as described previously. Those found to contain surfactant were pooled according to the respective sample. Fractions containing surfactant were washed (in $0.025 \mathrm{M}$ trometamol buffer, $\mathrm{pH}$ $7 \cdot 0)$ free of sucrose from the gradient by an initial centrifugation at $7700 \mathrm{~g}$ for 30 minutes $\left(4^{\circ} \mathrm{C}\right)$ and a second centrifugation at $9800 \mathrm{~g}$ for 15 minutes $\left(4^{\circ} \mathrm{C}\right)$.

Table 2 Preparation of controls and mixtures for HPLC analysis

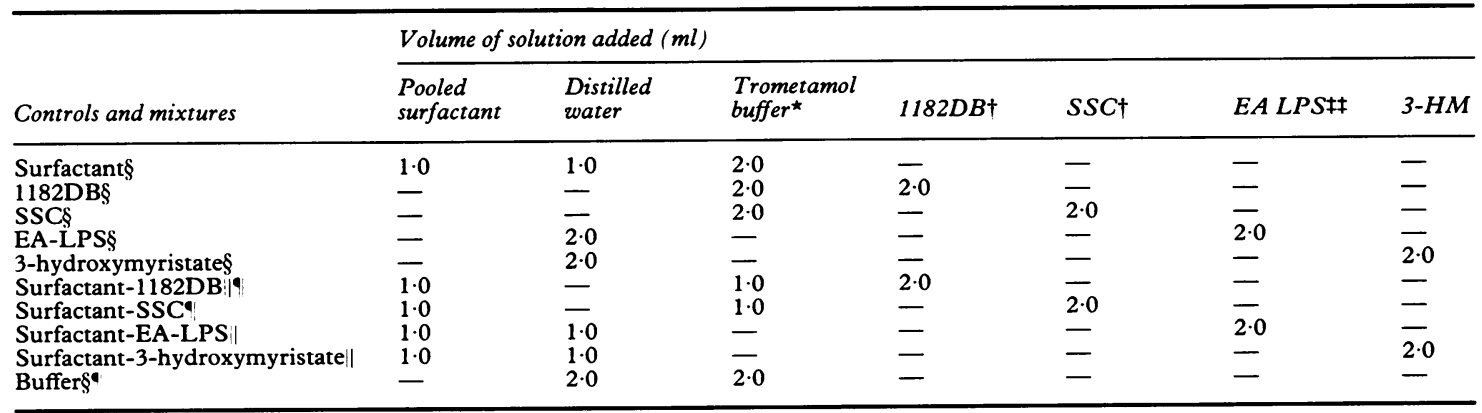

$\star 0.05 \mathrm{M}$ trometamol buffer, pH $7 \cdot 2$, with $0.002 \% \mathrm{NaN}_{3}$.

tAqueous extract $(1.0 \%$, w:v) of bulk cotton dust (1182DB) and SSC.

++ Purified Enterobacter agglomerans (EA) lipopolysaccharide (LPS) $(2 \mathrm{mg} / \mathrm{ml} \mathrm{0.05M}$ trometamol buffer).

§Controls.

Mixtures using 0.05M trometamol buffer, $\mathrm{pH} 7 \cdot 2$, with $0.004 \% \mathrm{NaN}_{3}$.

- Cotton extract concentration was $0.5 \%$ of the original sample after sample preparation. 
The washed samples were resuspended in $4.0 \mathrm{ml}$ of $0.025 \mathrm{M}$ trometamol buffer, $\mathrm{pH} 7.0$, with $0.001 \%$ $\mathrm{NaN}_{3}$, and stored at $4^{\circ} \mathrm{C}$ until needed.

An aliquot $(100 \mu \mathrm{l})$ of each of the controls and mixtures was evaporated to dryness under nitrogen. The residue was hydrolysed with $10.0 \mathrm{ml}$ of $4.0 \%$ $\mathrm{NaOH}$ in $50.0 \%$ ethanol in a $90^{\circ} \mathrm{C}$ water bath for one hour. The sample was allowed to cool to room temperature and acidified with $10.0 \mathrm{ml}$ of $5.0 \%$ sulphuric acid. Pyrogen free water $(10 \mathrm{ml})$ was added and this mixture was extracted three times with petroleum ether. The extracts were combined, evaporated to dryness, and phenacyl esters were prepared by reacting the dried material with $25 \cdot 0 \mu \mathrm{l}$ of phenacyl bromide and $25.0 \mu \mathrm{l}$ of triethylamine. This mixture was heated for 15 minutes in a boiling water bath, an additional $25 \cdot 0 \mu \mathrm{l}$ of triethylamine was added, and the mixture was heated for another 15 minutes. Acetic acid in acetone $(35.0 \mu \mathrm{l})$ was added and the mixture heated for five minutes in boiling water to remove excess reagent. All solvent was removed by evaporation with a flow of nitrogen gas and the residue dissolved in $200 \mu \mathrm{l}$ of acetonitrile.

Five microlitres of the phenacyl esters were analysed on a Waters (Milford, MA) HPLC equipped with a lambda-max model 480 ultraviolet detector, model $6000 \mathrm{~A}$ pump system, and RCM 100 radial compression module with a C18 column. Detection was at $242 \mathrm{~nm}$. Separation was isocratic using an $80: 20$ acetonitrile water mobile phase at a flow rate of $5 \mathrm{ml} / \mathrm{min}$. Peak areas were quantitated using Computer Automated Laboratory Services (CALS) software developed by computer inquiry services division of Beckmann, Inc (Fullerton, CA) on a Hewlett-Packard (Palo Alto, CA) 1000 computer.

In a complementary experiment endotoxin was also determined in the cotton extracts $1182 \mathrm{DB}$ and SSC) and surfactant controls by means of the limulus amoebocyte lysate (LAL) test (associates of Cape Cod, Woods Hole, MA). The cotton extract samples used here contained $1.0 \%$ of the original samples. Duplicate serial twofold dilutions of the samples were prepared in sterile, pyrogen free water. All glassware was depyrogenated by heating overnight at $180^{\circ} \mathrm{C}$. After the appropriate dilutions were inoculated into LAL tubes, the inoculated tubes along with positive and negative controls were incubated for one hour in a $37^{\circ} \mathrm{C}$ water bath. The sensitivity of the LAL test was $0.03 \mathrm{EU} / \mathrm{ml}$ checked against Escherichia coli control standard endotoxin (Associates of Cape Cod). To obtain the amount of endotoxin (ng) present in each sample the test results were divided by five. After incubation, the endpoint clot method was used to determine endotoxin concentration.

The statistical significance of the data was determined by analysis of variance ${ }^{42}$ and Fisher's least significant difference test ( $t$ test). The confidence intervals for the true mean surface tensions were also determined. It was necessary to transform the data because of the need to equalise the variables.

\section{Results}

After six hours incubation, the surfactant-1182DB was most striking in its difference from the other samples due to the presence of a floccule (figure). The sucrose density gradient centrifugation indicated that cotton extracts (1182DB and SSC) had no visible bands whereas the surfactant control and the mixtures did. Little difference was seen between the surfactant control and the surfactant-SSC mixture, although other data did indicate the formation of a complex between surfactant and SSC.

Analysis of sucrose gradient fractions, by phosphorus content and TLC, indicated that surfactant phospholipid was present in the surfactant control and in the appropriate band in all mixture tubes (table 3). Phospholipid, however, was not detected in the 1182DB and SSC control samples. The findings indicate slight changes in density for surfactant when incubated with the bulk cotton dust and sterile surgical cotton extracts.

Results of the LAL tests indicated that no endotoxin was present in the surfactant sample. A large amount $(9.6 \mathrm{mg} / \mathrm{ml})$ of endotoxin, however, was detected in the 1182DB (bulk dust) sample and a much smaller concentration of endotoxin $(30 \mathrm{ng} / \mathrm{ml})$ in the SSC. It is probable that the endotoxin value for $1182 \mathrm{DB}$ is inaccurate and highly inflated. Although non-endotoxin components can result in inflated LAL values ${ }^{4344}$ the results do indicate that the 1182DB extract has a much higher endotoxin content than the SSC extract.

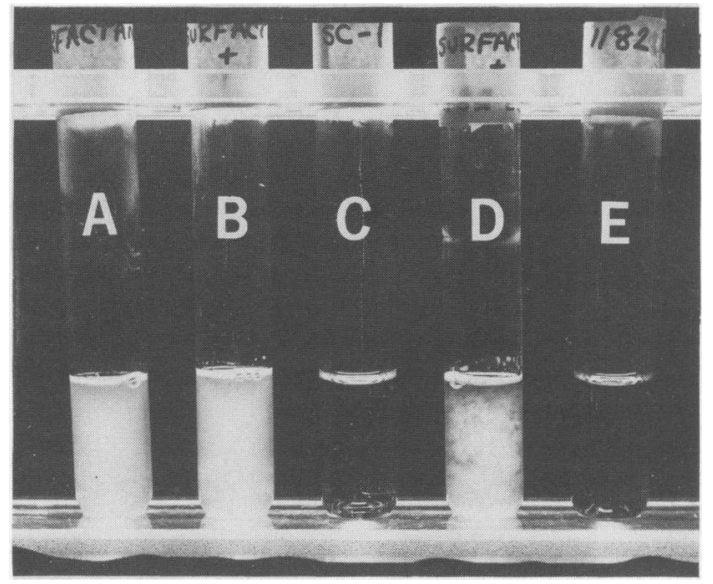

Mixtures, afer incubation at $37^{\circ} \mathrm{C}$ for six hours, containing; $A$, surfactant; $B$, surfactant $+S S C ; C, S S C ; D$, surfactant + bulk raw cotton dust (1182DB); E, $1182 D B$. Note floccule in surfactant-1182DB mixture tube. 
Table 3 Comparison of fractions collected after sucrose density gradient centrifugation of sheep lung surfactant, aqueous extracts of $1182 D B^{\star}$ and $S C C^{\star}$, and surfactant-1182DB and surfactant-SSC

\begin{tabular}{|c|c|c|c|c|}
\hline Sample & $\begin{array}{l}\text { Sucrose density }(\mathrm{g} / \mathrm{ml}) \\
\text { of fractions } \\
\text { containing phosphorus }\end{array}$ & $\begin{array}{l}\text { Fraction } \\
\text { No }\end{array}$ & $\begin{array}{l}\text { Surfactant } \\
\text { phospholipids } \dagger\end{array}$ & $L P S \ddagger$ \\
\hline $\begin{array}{l}\text { Surfactant } \\
1182 \mathrm{DB} \\
\text { SSC } \\
\text { Surfactant }-1182 \mathrm{DB} \\
\text { Surfactant }- \text { SSC }\end{array}$ & $\begin{array}{l}1.056-1.066 \\
\text { None } \\
\text { None } \\
1.052-1.066 \\
1.058-1.066\end{array}$ & $\begin{array}{l}10-12 \\
- \\
\overline{10-11} \\
10-12\end{array}$ & $\begin{array}{l}+ \\
\overline{+} \\
+ \\
+\end{array}$ & $\begin{array}{l}- \\
\overline{-} \\
+ \\
+\end{array}$ \\
\hline
\end{tabular}

^Aqueous extracts $(1 \cdot 0 \%, \mathrm{w}: \mathrm{v})$ of bulk cotton dust $(1182 \mathrm{DB})$ and SSC.

+ Identified by TLC.

$\ddagger$ Presence of lipopolysaccharide (LPS) indicated by the presence of 3-HM.

Table 4 Means and results of significant-difference test ( $t$ test) for surface tension values for sheep lung surfactant, aqueous extracts of $1182 D B^{\star}$ and $S S C^{\star}$, and surfactant$1182 D B$ and surfactant-SSC

\begin{tabular}{llll}
\hline Sample & $\begin{array}{l}\text { No of } \\
\text { replicates }\end{array}$ & $\begin{array}{l}\text { Mean surface } \\
\text { tension } \dagger \\
\text { (dynes } / \text { cm })\end{array}$ & $\begin{array}{l}95 \% \\
\text { Confidence } \\
\text { interval } \dagger\end{array}$ \\
\hline Surfactant & 50 & $32.5 \mathrm{~A}$ & $31 \cdot 9-33 \cdot 1$ \\
1182DB & 40 & $65.9 \mathrm{~B}$ & $63 \cdot 4-68 \cdot 4$ \\
SSC & 20 & $74.0 \mathrm{C}$ & $72 \cdot 7-75 \cdot 3$ \\
Surfactant - 1182DB & 40 & $52.3 \mathrm{D}$ & $49 \cdot 7-54 \cdot 8$ \\
Surfactant - SSC & 40 & $50.9 \mathrm{D}$ & $48 \cdot 7-53 \cdot 1$ \\
\hline
\end{tabular}

*Aqueous extracts $(1.0 \%$, w:v) of byssinotic cotton dust (1182DB) and sterile, surgical cotton (SSC).

†Means with the same letter are not significantly different.

$\dagger+$ The lower and upper limits are not equidistant from their respective means due to the necessary transformation performed on the data.

Table 5 Presence of 3-hydroxymyristic acid (3-HM) in controls and mixtures by HPLC

\begin{tabular}{lll}
\hline Sample & $\begin{array}{c}\text { Peak } \\
\text { area }\end{array}$ & $\begin{array}{l}\text { Amount of 3-HM } \\
\text { present }(\mu g)\end{array}$ \\
\hline 3-HM & $222 \cdot 7$ & $100 \cdot 0$ \\
Surfactant & $\mathrm{ND}+\dagger$ & $\mathrm{ND}$ \\
1182DB & $\mathrm{ND}$ & $\mathrm{ND}$ \\
SSC $^{\star}$ & $\mathrm{ND}$ & $\mathrm{ND}$ \\
Enterobacter agglomerans LPS & $123 \cdot 5$ & $55 \cdot 5$ \\
Surfactant-1182DB & $0 \cdot 7$ & $0 \cdot 3$ \\
Surfactant-SSC & $\mathrm{ND}$ & $\mathrm{ND}$ \\
Surfactant-E agglomerans LPS & $2 \cdot 1$ & $0 \cdot 9$ \\
Surfactant-3-HM & $31 \cdot 4$ & $14 \cdot 1$ \\
Buffer $\dagger$ & $\mathrm{ND}$ & $\mathrm{ND}$ \\
\hline
\end{tabular}

*Aqueous extracts $(1.0 \%, \mathrm{w}: \mathrm{v})$ of byssinotic cotton dust (1182DB) and SCC.

t0.05 $\mathrm{M}$ trometamol buffer, $\mathrm{pH} 7 \cdot 2,0.002 \% \mathrm{NaN}_{3}$.

$++\mathrm{ND}=$ None detected.

Significant differences in values for surface tension were found between the surfactant, $1182 \mathrm{DB}$, and SSC controls. Also, there were statistically significant distinct surface tension values between the complexes and the controls. This confirmed the formation of complexes between surfactant and the bulk dust (1182DB) and the sterile surgical cotton (SSC) extracts (table 4). The surfactant mixtures containing the cotton extracts had significantly altered surface tension values compared with those of the surfactant and SSC controls.

The data in table 5 indicate that 3-HM was not detected by HPLC in the buffer, surfactant, $1182 \mathrm{DB}$, and SSC controls. It was also not found in the surfactant-SSC complex. As HPLC cannot detect 3-HM below a concentration of $500 \mathrm{ng}^{45}$ and LAL indicated only $30 \mathrm{ng}$ LPS per ml of SSC this is not surprising. This fatty acid, however, was found in the $E$ agglomerans LPS and 3-HM controls, and the surfactant mixtures with 3-HM $E$ agglomerans LPS, and $1182 \mathrm{DB}$ extracts.

The calculated values from HPLC peak areas indicated that the largest amount of 3-HM detected was, as expected, in the 3-HM control. The next largest amount was in the EA-LPS control, then the surfactant-3HM complex, the surfactant-EA-LPS complex, and the surfactant-1182DB complex.

\section{Discussion}

The 1182DB extract profoundly affected the lung surfactant by causing a flocculation (or precipitation) of the surfactant. This effect was absent in the complex formed between surfactant and the SSC. In earlier work ${ }^{32}$ this phenomenon was not observed when purified $E$ agglomerans LPS was mixed with lung surfactant at high concentration (1 mg LPS: $1 \mathrm{ml}$ surfactant). As the final $1182 \mathrm{DB}$ dust concentration in the complex mixture was $0.5 \%$, the actual weight of dust material could be no greater than $5.0 \mathrm{mg} / \mathrm{ml}$. This would contain not only LPS but also many other plant and microbial compounds. Therefore, the actual amount of LPS would be much lower. This is confirmed by the HPLC data. Using the amount of purified $E$ agglomerans LPS $(4.0 \mathrm{mg})$ mixed with the surfactant, the amount used in the $E$ agglomerans LPS control $(4.0 \mathrm{mg})$, and comparing the peak area of the surfactant-1182DB sample (0.7) with that of the $E$ agglomerans LPS control sample (123.5), it is possible to estimate the amount of LPS in the surfactant-1182DB complex. This value is $0.02 \mathrm{mg}$, which is much less than that used in the earlier study. ${ }^{32}$ The data therefore suggest another 
compound(s), other than LPS, in the 1182DB sample may be responsible for the flocculation of the surfactant. Perhaps this is a lectin mediated reaction, since alone, surfactant precipitates with $\mathrm{N}$-acetylglucosamine and to a lesser extent with $\mathrm{N}$-acetylgalactosamine. ${ }^{46}$

Results of HPLC showed that 3-HM was present in purified $E$ agglomerans LPS and the $E$ agglomerans LPS-surfactant complex, but not the surfactant control. Results indicate that the LPS bound to the surfactant. The inability to detect 3-HM in the $1182 \mathrm{DB}$ ccontrol, although it is detectable in the surfactant-1182DB complex, suggests that in the $1.0 \%$ aqueous extract of the bulk raw cotton dust the 3-HM component of lipid A is of too low a concentration to be detected by HPLC. It has been shown that 3-HM cannot be detected by HPLC at or below a concentration of $500 \mathrm{ng} .{ }^{45}$ As the data on surface tension indicate that LPS binds to surfactant, it is possible that LPS has an affinity for the surfactant, thereby concentrating 3-HM to a detectable concentration. The LAL test indicated that the endotoxin concentration was about $30 \mathrm{ng} / \mathrm{ml}$ in the sterile surgical cotton extract. This concentration (30 ng/ $\mathrm{ml}$ ) is below the detectable range of 3-HM by HPLC, ${ }^{45}$ and may explain why the high surface tension values of surfactant-SSC mixture indicated that a complex was formed although no 3-HM was observed in this sample. The lipid moiety present in LPS is hydrophobic, ${ }^{40}$ whereas phospholipids, the major components of lung surfactant, are amphipathic. It is plausible that the complexing that occurred between LPS and surfactant may be due to hydrophobic hydrophilic bonding between the lipid A moiety of the LPS and the phospholipid portion of the surfactant.

Several observations can be made from the data in table 5 . In both the EA-LPS control and the surfactant-EA-LPS complex, the amount of EA-LPS (and, therefore, $3-\mathrm{HM})$ is the same $(1 \mathrm{mg} / \mathrm{ml})$. The data indicate that not all the EA-LPS available during the mixing procedure, did, in fact, bind to the surfactant. Only about $1.6 \%$ of the available EA-LPS (or 3$H M$ ) bound to the surfactant. On comparison of the 3-HM and surfactant-3 HM complex data it is apparent that more 3-HM was bound in this complex $(14.1 \%)$ than in the surfactant-EA-LPS complex. It is possible that steric hindrance prevents any further 3-HM in the EA-LPS from binding to the surfactant.

Surfactant is important to homeostasis and alveolar stability in the lung. ${ }^{14}{ }^{15}$ It has also been shown to play a vital part in the prevention of allergic reaction in the lung ${ }^{16}$ and enhances the ability of alveolar macrophages to combat infection..$^{120}$ Atelectasis can occur in newborn babies functionally deficient in lung surfactant. ${ }^{21}$ Altered lung surfactant is associated with several pulmonary diseases such as adult respiratory distress syndrome and hyperoxia. ${ }^{22-24}$ The data in this study suggest that alteration of biophysical properties of lung surfactant by inhalation of raw bulk cotton dust could compromise the biological function of lung surfactant.

This could result in the onset of the symptoms observed in the Manchester criteria. ${ }^{4}$ For example, inhalation of as little as $10 \mu \mathrm{g}$ of Escherichia coli LPS has been shown to elicit a febrile response. ${ }^{49}$ Lipopolysaccharide also causes inflammation in respiratory airways as seen in the influx of neutrophils and macrophages..$^{50-52}$ It has been shown to cause structural and metabolic changes in pulmonary endothelial cells and increase in permeability of the endothelial layer..$^{53}$ Tannins, common constituents of cotton dusts, are potent cytotoxins of pulmonary arterial endothelial cells ${ }^{54}$ and may contribute to the acute inflammatory response of byssinosis..$^{556}$ Other compounds found in cotton dusts are biologically active and may cause damage once they reach the pulmonary tissues. These include bacterial peptides, glucan, byssinosin, and Iacinilene C. ${ }^{57}{ }^{58}$ Alteration of lung surfactant by water soluble cotton dust constituents (such as LPS) could therefore play a part in the pathogenesis of byssinosis by not only affecting the physiological function of the surfactant itself but also aiding the passage of biologically active compounds into the pulmonary tissues.

Requests for reprints to: Anthony J DeLucca II, Southern Regional Research Center, USDA-ARS, PO Box 19687, New Orleans, Louisiana 70179, USA.

1 Fischer JJ, Kylberg K. Microbial flora associated with cotton plant parts and the air of cotton mills. In: Wakelyn PJ, Jacobs $\mathrm{RR}$, eds. Proceedings seventh cotton dust research conference. 1983 Beltwide cotton production research conferences. San Antonio, Texas: National Cotton Council, 1983:36-7.

2 Pervis B, Vigliani EC, Cavagna C, Finulli $M$. The role of bacterial endotoxins in occupational diseases caused by inhaling vegetable dusts. $\mathrm{Br} J$ Ind $\mathrm{Med}$ 1961;18:120-9.

3 Tuffnell $P$. The relationship of byssinosis to the bacteria and fungi in the air of textile mills. Br J Ind Med 1960;17:304-6.

4 Rylander R, Schilling RSF, Pickering CAC, Rooke GB, Dempsey AN, Jacobs RR. Effects after acute and chronic exposure to cotton dusts: the Manchester criteria. $\mathrm{Br} J$ Ind Med 1987;44:577-9.

5 Cinkotai FF, Whitaker CJ. Airborne bacteria and the prevalence of byssinotic symptoms in 21 cotton spinning mills in Lancashire. Ann Occup Hyg 1978;21:239-50.

6 Ellakkani MA, Alarie Y, Weyel D, Karol MH. Chronic pulmonary effects in guinea pigs from prolonged inhalation of cotton dust. Toxicol Appl Pharmacol 1987;88:354-9.

7 Castellan RM, Olenchock SA, Hankinson JL, et al. Acute bronchconstriction induced by cotton dust: dose-related response to endotoxin and other dust factors. Ann Intern Med 1984;101:157-63.

8 Petsonk EL, Olenchock SA, Castellan RM, et al. Human ventilatory response to washed and unwashed cottons from different growing areas. $\mathrm{Br} J$ Ind Med 1986;43:182-7.

9 Rylander R. Organic dusts and lung reactions-exposure characteristics and mechanisms for disease. Scand $J$ Work Environ Health 1985;11:199-206.

10 Bottoms GD, Johnson M, Ward D, Fessier J, Lamar C, Turek J. Release of eicosanoids from white blood cells, platelets, smooth muscle cells, and endotoxin and A23187. Circ Shock 1986;20:25-34.

11 Rylander $R$, Beijer L. Inhalation of endotoxin stimulates alveolar macrophage production of platelet-activating factor. Am Rev Res Dis 1987;135:83-5.

12 Witek TJ, Gundel RH, Wegner CD, Schachtler EN, Buck MG. Acute pulmonary response to cotton bract in monkeys: lung 
function and effects of mediator modifying compounds. Lung 1988;166:25-31.

13 Rooney SA. The surfactant system and lung phospholipid biochemistry. Am Rev Respir Dis 1985;131:439-60.

14 Clements JA, Tiernly DF. Alveolar inability associated with altered surface tension. In: Fern WO, Rahn H, eds. Respiration. Washington: American Physiological Society, 1965: 1565-83.

15 Hills BA. Biophysics of the surfactant system of the lung. In: Cosmi EV, Scarpelli EM, eds. Pulmonary surfactant system. New York: Elsevier Science Publishers, 1983:17-32.

16 Becher G. Lung surfactant prevents allergic bronchial constriction in ovalbumin sensitised guinea pigs. Biomed Biochim Acta 1985; 44:K57-61.

17 Emerson RJ, Davis GS. Effects of alveolar lining materialcoated silica on rat alveolar macrophages. Environ Health Perspect 1983;51:81-4.

18 Jarstrand $C$. Role of surfactant in the pulmonary defense system. In: Robertson B, Van Golde LMG, Batenburg JJ, eds. Pulmonary surfactant. Amsterdam: Elsevier, 1984:187-201.

19 Schartz W, Christman CA. Alveolar macrophage migration influences of lung lining material and acute lung insult. $\mathrm{Am}$ Rev Respir Dis 1979;120:429-39.

20 O’Neill S, Lesperance E, Klass DJ. Rat lung lavage surfactant enhances bacterial phagocytosis and intracellular killing by alveolar macrophages. Am Rev Respir Dis 1984;130:225-30.

21 George G, Hook GER. The pulmonary extracellular lining. Environ Health Perspect 1984;55:227-37.

22 Hallman M, Spragg R, Harrell JH, Moser KM, Gluck L. Evidence of lung surfactant abnormality in respiratory failure. $J$ Clin Invest 1982;70:673-83.

23 Gross NJ, Smith DM. Impaired surfactant phospholipid metabolism in hyperoxic mouse lungs. $J$ Appl Physiol 1981;51:1198-203.

24 Holm BA, Notter RH, Siegle J, Matalon S. Pulmonary physiological and surfactant changes during injury and recovery from hyperoxia. J Appl Physiol 1985;59:1402-10.

25 Rooney SA. Lung surfactant. Environ Health Perspect 1984;55:205-26.

26 Brogden KA, Cutlip RC, Lehmkuhl HD. Complexing of bacterial lipopolysaccharide with lung surfactant. Infect Immun 1986;52:644-49.

27 Brogden KA, Rimler RB, Cutlip RC, Lemkuhl HD. Incubation of Pasteurella haemolytica and Pasteurella multocida lipopolysaccharide with sheep lung surfactant. Am J Vet Res 1986;47:727-9.

28 De Lucca II, AJ, Palmgren MS. Mesophillic microorganisms and endotoxin levels on developing cotton plants. $\mathrm{Am}$ Ind $\mathrm{Hyg}$ Assoc $J$ 1986;47:437-42.

29 De Lucca II, AJ, Schaffer GP, Berni RJ. Analysis of epiphytic bacteria and endotoxin during cotton plant maturation. $A m$ Ind Hyg Assoc J 1988;49:539-45.

30 Rylander R, Lundholm M. Bacterial contamination of cotton and cotton dusts and effects on the lung. $\mathrm{Br} J$ Ind Med 1978;35:204-7.

31 Gokani VN, Doctor PB, Gosh SK. Isolation and identification of gram-negative bacteria from raw baled cotton and synthetic textile fibers with special reference to environment GNB and endotoxin concentrations of textile mills. Am Ind Hyg Assoc J 1987;48:511-4.

32 De Lucca II, AJ, Brogden KA, Engen R. Enterobacter agglomerans lipopolysaccharide-induced changes in pulmonary surfactant as a factor in the pathogenisis of byssinosis. $J$ Clin Microbiol 1988;36:778-80.

33 Jobe A, Ikegami M, Glatz T, Yoshida Y, Diakomanozis E, Padbury J. Duration and characteristics of treatment of premature lambs with natural surfactant. J Clin Invest 1981;677:370-5.

34 Bligh EG, Dyer WJ. A rapid method of total lipid extraction and purification. Canadian Journal of Biochemistry and Physiology 1959;37:911-7.

35 Westphal O, Jann K. Bacterial lipopolysaccharides: extration with hot phenol-water and further applications of the procedure. In: Whistler RL, Walfrom ML, eds. Methods in carbohydrate chemistry, vol 5. New York: Academic Press, 1965:83-91.

36 Charvardijan A, Rudniki E. Determination of lipid phosphorus in the nanomolar range. Anal Biochem 1970;36:225-6.

37 Touchstone JC, Chen JC, Beaves KM. Improved separation of phospholipids in thin layer chromatography. Lipids 1980;15:61-2.

38 Du Nouy PL. A new apparatus for measuring surface tension. $J$ Gen Physiol 1919;1:521.

39 Brondz I, Olsen I. Determination of acids in whole lipopolysac- charide and in free lipid A from Actinobacillus actinomycetemcomitans and Haemophilus aphrophitus. J Chromatogr 1984;308:19-29.

40 Galanos C, Luderitz O, Reitschal ET, Westphal O. Newer aspects of the chemistry and biology of bacterial lipoplysaccharides, with special reference to their lipid A component. In Goodwin TW, ed. International review of biochemistry. Biochemistry of lipids II, vol 14. Baltimore: University Park Press, 1977:239-335.

41 Maitra SK, Nachum R, Pearson FC. Establishment of betahydroxy fatty acids as chemical marker molecules for bacteria endotoxin by gas chromatography-mass spectrometry. $A p p$ Environ Microbiol 1986;52:510-14.

42 SAS Institute Inc, SAS/STAT guide for personal computers, version 6. Cary, NC: SAS Institute Inc, 1985.

43 Elin RJ, Wolfe SM. Biology of endotoxin. Annual Reviews of Medicine 1976;27:127-41

44 Kotani S, Watanabe Y, Kinoshita F, et al. Gelatin of amoebocyte lysate of Tachypleus tridentatus by cell wall digest of several gram-positive bacteria and synthetic peptidoglycan subunits of natural and unnatural configurations. Biken $J$ 1977;20 5-10.

45 Morris NM, Catalano EA, Berni RJ. 3-Hydroxymyristic acid as a measure of endotoxin in cotton lint and dust. Am Ind Hyg Assoc $J$ 1988;49:81-8.

46 Brogden KA, Adlam C, Lehmkuhl HD, Cutlip RC, Knights JM, Engen RL. Effect of Pasteurella haemolytica (A1) capsula polysaccharide on sheep lung in vivo and on pulmonary surfactant in vitro. Am J Vet Res 1989;50:555-9.

47 Albert RK, Lakshimarayan SL, Hildebrant J, Kirk W, Butler J Increased surface tension favors pulmonary edema formation in anesthetised dog's lungs. J Clin Invest 1979;63:1015-8.

48 Sutnick AI, Soloff LA. Atelectasis with pneumonia: a pathophysiologic study. Ann Intern Med 1964;60:39-46.

49 Haglind P, Bake B, Rylander R. Effects of endotoxin inhalation challenges in humans: In: Wakelyn PJ, ed. Proceedings 8 th cotton dust research conference. 1984 Beltwide cotton production research conferences. San Antonio, Texas: National Cotton Council, 1984:105-6.

50 Folkerts G, Henricks PAJ, Slootweg PJ, Nijamp FP. Endotoxininduced inflammation and injury of the guinea pig respiratory airways cause bronchial hyporeactivity. Am Rev Respir Dis 1988;137:1441-8.

51 Meyrick B, Brigham K. Acute effects of Escherichia coli endotoxin on the pulmonary microcirculation of anesthetized sheep. Structure: function relationships. Lab Invest 1983;48:458-70.

52 Snella M-C, Rylander R. Endotoxin inhalation induces neutrophil chemotaxis by alveolar macrophages. Agents Actions 1985;16:521-6.

53 Meyrick BO, Ryan US, Brigham KL. Direct effects of $E$ coli endotoxin on structure and permeability of pulmonary endothelial monolayers and the endothelial layer of intimal explants. Am J Pathol 1986;122:140-51.

54 Johnson CM, Hanson MN, Rohrbach MS. Endothelial cell cytotoxicity of cotton bracts tannin and aqueous cotton bracts extract: tannin is the predominant cytotoxin present in aqueous cotton bracts extract. Environ Health Perspect 1986;66:97-104.

55 Lauque DE, Schroeder MA, Russell JA, Rohrbach MS. Comparison of the acute pulmonary inflammatory response to inhaled cotton dust extract and tannin. In: Jacobs RR, Wakelyn PJ, eds. Proceedings 12 th cotton dust research conference. 1988 Beltwide cotton production research conferences. New Orleans, Louisiana: National Cotton Council, 1988: 87-9.

56 Specks U, Kreofsky TJ, Limper AH, Brutinel WM, Rohrbach MS. Tannin mediates the secretion of neutrophil chemitactic factor from alveolar macrophages in rabbits and humans. In: Proceedings 13th cotton dust research conference. 1989 Beltwide cotton research conferences. Nashville, Tennessee: National Cotton Council, 1989:79-81.

57 Jacobs RR. Review of the etiology and pathogenesis of byssinosis: historical perspective. In: Wakelyn PJ, Jacobs RR, eds Proceedings 7 th cotton dust research conference. 1983 Beltwide cotton production research conferences. San Antonio, Texas, National Cotton Council, 1983:7-10.

58 Rylander R, Goto H, Marchat B. Acute toxicity of inhaled beta, 1-3 glucan and endotoxin. In: Jacobs RR, Wakelyn PJ, eds. Proceedings 13th cotton dust research conference. 1989 Beltwide cotton research conferences. Nashville, Tennessee: National Cotton Research Conference, 1989:145-6.

Accepted 11 June 1990 